\title{
Originality of the Semantic Approach in Arabic Linguistic Thought, with Particular Reference to Ibn al-Qațțā's Work
}

\author{
FRANCESCO GRANDE (Università Ca’ Foscari Venezia)
}

\begin{abstract}
In this study we investigate some aspects of the linguistic thought of Ibn al-Qattāa (d. 515/1121) with the intent of contributing to a better knowledge of this eminent personality of Arab Muslim Sicily. To this aim, we offer a description of the milieu of linguistic thought to which al-Qatțā belonged, with particular reference to some members of that milieu, who are known to modern scholars for efforts distinguished by theoretical and methodological originality. We also clarify some semantically-oriented original traits of Ibn alQațțā's morphological analysis, as emerging from his treatise Kitāb 'abniyat al-'asma $\bar{a}^{\prime}$ wa'l-'af'äl wa'lmașādir, as precisely such traits make it possible to number him among the infrequent bearers of semantic originality in the context of medieval Arabic linguistic thought.
\end{abstract}

Key words: Ibn al-Qatțāe , originality, morphology, semantics

\section{Arabic linguistic thought, conservatism and originality}

From an historical perspective, the chronological limits within which linguistic thought developed in the medieval Arab Muslim world can be set approximately between 180/796, the date of Sỉbawayhi's death, and 911/1505, the date of al-Suyūțī's death. ${ }^{1}$ If we turn to epistemological considerations, modern scholars have long noticed that, within that timespan, Arabic linguistic thought is characterized by strong conservatism in terms of objectives, contents and methodology. However, modern scholars differ in their assessment of this phenomenon. In asserting that "les grammairiens arabes se sont fastidieusement répétés, copiés les uns les autres", Fleisch ${ }^{2}$ is reluctant to judge such conservatism positively; whereas Guillaume ${ }^{3}$ gives the opposite advice when he affirms that Arabic linguistic thought "was founded on a remarkably self-consistent set of general principles (of axioms, so to speak) defining its object, its aims, and its methods".

In particular, in the methodology of Arabic linguistic thought, and particularly in grammatical description, conservatism mainly manifests itself as the tendency, on the part of different schools (Kufan, Basran, Baghdadian, Andalusian, Egyptian ${ }^{4}$ ), to focus linguis-

1 CARTER 2007: 184, 189. The date of Sỉbawayhi's death is not a matter of certainty. Here, his death is dated to 180/796 following BAALBAKI 2002: 1, BAALBAKI 2008: 1 and BAALBAKI 2014: 2.

2 FLEISCH 1961, i: 46.

3 Guillaume 2007: 175.

4 DAYF 1968: 241-2. 
tic analysis on the level of form rather than of meaning. ${ }^{5}$ In all likelihood, the historical reason that lies behind this attitude is the obscurity that the Arab grammarians and lexicographers might have perceived in the variety of Arabic they wanted to describe, the so-called kaläm al- $\mathrm{Arab}^{6}{ }^{6}$ It can be hypothesized, in fact, that in transmitting and investigating the kalām al-'Arab, the Arab grammarians and lexicographers not so infrequently took great pains in understanding it, so they felt somehow forced to access it primarily through its form rather than its meaning, the former being clearer to them than the latter. It is telling in this respect that precisely the study of obscure words $(\dot{g} a r i b)$ was an important part of the Arab lexicographers' work since the very beginnings of Arabic linguistic thought, ${ }^{7}$ though further investigation is required to validate such a hypothesis. ${ }^{8}$

Be that as it may, the fact that conservatism tends to tally with a formal approach in the methodology of Arabic linguistic thought implies that the rare traits of originality present take place on the level of meaning. This is illustrated by al-Ğurğānī’s (d. 471/1078) interpretation of the word-order pair ğumla ismiyya-ğumla filiyya, e.g., al-zaydūna katabü / kataba al-zaydūna 'the Zayds, they wrote/the Zayds wrote'. ${ }^{9}$ While Arabic linguistic thought usually derives this syntactic pair from a formal opposition, which consists of the agreement, or lack thereof, between the verb and the noun, ${ }^{10}$ al-Ğurğānī interprets it as the result of a semantic opposition, in which informational saliency affects either the utteranceinitial noun (i.e, al-zaydūna in al-zaydūna katabü) or the utterance-initial verb (i.e., kataba in kataba al-zaydūna). ${ }^{11}$

\footnotetext{
5 VERSTEEGH 1997: 228
}

6 Technically speaking, the definition of this variety of Arabic is quite fluid in the literature. A matter of wide consensus among Arabists is that kalām al- ${ }^{-} \mathrm{Arab}$ is basically the linguistic material attested to in the Koran and pre-Islamic poetry (GUILLAUME 2007: 177), but according to some definitions it may also include the linguistic data collected from the Bedouin ( $\mathrm{kalamm} \mathrm{al-'}$ Arab) and even the Prophet's sayings (hadīt ): cp. BAALBAKI 2014: 30, 37. See also LEVIN 1999: 270 for a narrower definition of the variety of Arabic under discussion.

7 BAALBAKI 2014: 7, 36-37.

8 Outside Arabic, it is well established among linguists that an epistemological connection exists between an obscure language and the resort to a formal approach to analyze it. Lepschy exemplifies this state of affairs by means of the formal approach that American structuralists developed to account for Amerindian languages, which effectively appeared rather puzzling to them (LEPSCHY 1966: 151-2).

9 Cp. VersteEgh 1997: 259-260.

10 Al-Ğurğānī himself adheres to this formal interpretation in terms of syntactic agreement in his work al-

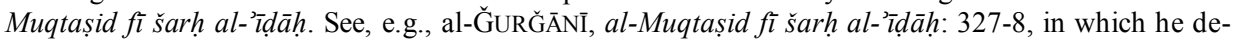
fines the element that can co-occur with the verb of a gumla ismiyya and cannot co-occur with the verb of a ğumla fi liyya as a unit that carries syntactic information and is incorporated into that verb (l-fā $i l$ $k a^{\prime} l-g u^{\prime} z^{\prime}$ min-a l-fi $\left.i^{\prime}\right)$, i.e., as a sort of agreement-marker. This passage reads as follows: wa- lam 'anna l-fā'ila ka'l-ğuz'i min-a l-fíli wa-li-dālika lam yağuz taqdīmu 'alay-hi nahwa 'an taqūla l-zaydāni d̦araba [...] fa-lammā lam yaqūlū 'illā darabā 'alimta 'anna l-zaydāni raf'u-humā bi'l-ibtidā'i wa'lfā'ila huwa l-'alifu fí darabā. On the different approaches of al-Ğurğān̄̄ 'grammarian' (al-Muqtașid fì

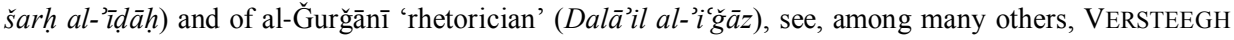
1997: 259-260.

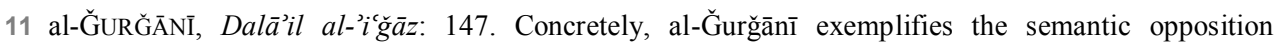
between ğumla ismiyya and ğumla fil liyya by means of interrogative utterances (al-istifhäm) such as ' $a$ fa'alta, 'a-'anta fa'alta. In these utterances, the informational saliency, which consists of the speaker's 
In the literature, few other examples of semantic traits of originality are seemingly reported, the most notable of which are those developed by al-Astarābā Ibn Hišām (d. 761/1359) ${ }^{13}$ By contrast, it seems that the semantic originality that Ibn alQatțāa (d. 515/1121) brought to Arabic linguistic thought has not yet received scholarly attention. In what follows, we first outline the main aspects of semantic originality of alAstarābā đ̄̄̄s's and Ibn Hišām's linguistic thought in the form of a review of the literature, then proceed to clarify the contribution of Ibn al-Qatțā in the same respect.

Yet before proceeding further, a caveat is in order: ascertaining the pervasiveness of a formal approach in the conservative transmission of Arabic linguistic thought should not mislead us into oversimplification. In the transmission of such knowledge, the semantic dimension was marginal but not totally absent. Evidence for this assertion comes from the formative stages of Arabic linguistic thought: as Baalbaki points out, ${ }^{14}$ Sĩbawayhi avails himself of "technical terms which refer to formal aspects" and which, at the same time, "have distinct semantic functions", although "[he] does not formulate a semantic theory in the Kitāb" for these terms, relegating them to a marginal role. We can draw an example from morphology to understand this point. In Sïbawayhi's view, the construct of affixation (ziyāda) can but must not involve a semantic dimension, contrary to standard assumptions in modern Western linguistics. On the one hand, Sībawayhi explicitly states that affixation may "introduce an element of meaning" (tadhulu li-ma'nan). ${ }^{15}$ On the other hand, he also asserts that this function is not quintessential to affixation, the other important function of it being that of ilhāq, i.e., "reducing one [anomalous] pattern to another [more regular] pattern" (tulhiqu bin $\bar{a}^{3}$ an li-bin $\bar{a}$ ) regardless of their meaning. ${ }^{16}$ For instance, the Arab grammarians regard the Quranic hydronym kawtar as instantiating an unexpected consonant $w$, which disrupts the regular pattern $f a^{c} a l$, thus yielding the anomalous pattern faw'al. They also propose to reconceptualize the unexpected consonant $w$ as an affix that, in merely formal terms, occupies the position of a root consonant ( $(i l h \bar{a} q)$, rather than introducing an element of meaning. This analysis allows them to re-interpret the anomalous pattern $f a w^{\prime} a l$ as a regular quadriconsonantal pattern, which is effectively attested to in nouns such as ğa $\mathrm{far} .{ }^{17}$

Furthermore, the formal approach itself was not immune from sporadic traits of originality, in spite of the Arab grammarians' tendency to transmit it conservatively from one generation to the next. An indicative example is the conceptual organization of Arabic grammatical theory devised by Ibn al-Sarrāğ (d. 316/928), the original character of which

doubt (šakk), affects either the utterance-initial verb fa'alta (fa-bada'ta bi'l-fi li kāna l-šakku fì l-fíl) or the utterance-initial (pro)noun 'anta (fa-bada'ta bi'l-ismi kāna l-šakku fí l-fā'il). Cp. also VERSTEEGH 1997: 259-260.

12 Guillaume 1998: 59-62.

13 GULLY 1995: 6, 56

14 BAALBAKI 2008: 173. Cp. also the discussion concerning the notion of fadla in the next section.

15 SīBAWAYHI, Kitāb, iii: 213. This translation is based on BAALBAKI 2002: 7.

16 SīBAWAYHI, Kitāb, iii: 213. In this connection Baalbaki himself remarks that "this ziyāda is different from the one which uniformly introduces an element of meaning": see BAALBAKI 2002: 3.

17 BAALBAKI 2002: 4. Cp. also SīBAWAYHI, Kitāb, iii: 211, which puts forward a similar analysis for fáwal (e.g., ğadwal). 
Guillaume ${ }^{18}$ highlights as follows: "The same preoccupation with clarifying the foundations of grammatical theory and with finding new, more explicit ways to formulate it is also perceptible in Ibn al-Sarrāğ's (d. 316/928) 'ușūl, a descriptive treatise following an entirely new and systematic order of exposition". Guillaume ${ }^{19}$ also highlights the isolated nature of this formal originality by observing that Ibn al-Sarrāğ's successors fossilized his conceptual organization of Arabic grammatical theory into a "canonical mode of exposition for grammatical treatises" so that "no major evolution occurred in subsequent centuries" for such a theory. ${ }^{20}$

Bearing this in mind, we can now address the issue of (non-marginal) semantic originality in Arabic linguistic thought.

\section{Al-Astarābādī and the Arabic system of case endings}

Raḍ̄ 1-Dīn Muhammad b. al-Ḥasan al-Astarābād̄ī was an Arab grammarian of Iranian origin. He was born on an unknown date in the city of Astarābā d (present-day Iran), which is traditionally described as producing scholars proficient in all the sciences. In alAstarābādī's time, however, the cultural potential of that milieu was probably limited by historical accidents, such as the Mongol invasions, which may explain why his commentary ( $\check{s} a r h)$ on the syntactic treatise Kăfiya of Ibn al-Ḥāğib (d. 646/1249) was not circulated or developed by subsequent grammarians in spite of his scholarly prowess. Another possible explanation for the inadequate reception of al-Astarābād̄īs commentary-with the notable exception of al-Suyūṭi (d. 911/1505) — was its innovative nature vis-à-vis the predominating conservatism of Arabic linguistic thought at that time. Al-Astarābādī may have died in $686 / 1287$ or more likely in $688 / 1289 .{ }^{21}$

The conservative methodology of Arabic linguistic thought we have just alluded to devoted considerable attention to the system of case endings ( $i^{c} r \bar{a} b$ ), which constituted a central feature of the variety of Arabic described by the Arab grammarians and lexicographers. The resulting theory stands out for its conceptual simplicity: briefly, ${ }^{22}$ what assigns the case ending to the noun is a particle or a verb ${ }^{23}$ that precedes the noun in question. As a corol-

18 GUILLAUME 2007: 176.

19 GUILLAUME 2007: 176.

20 The systematic character that originally informs Ibn al-Sarrāğ’s conceptual organization of grammar is apparent, for instance, from his description of the syntactic behavior of parts of speech in logicalcombinatorial terms. Cp. the key-word ya'talifu in the following passage (IBN al-SARRĀĞ, al-'Ușūl fì $l$ nahw, i: 41): wa-llad̄i ya'talifu minhu l-kalāmu l-talātatu l-ismu wa'l-fílu wa'l-harfu fa'l-ismu qad ya'talifu ma'a l-ismi... wa-ya'talifu l-ismu wa'l-fi'la [...] wa-lā ya'talifu l-fi'lu ma'a l-fi'li wa'l-harfu lā ya'talifu ma'a l-harf. See GHERSETTI, to appear for further details and references.

21 See Bohas, Guillaume, Kouloughli 1990: 72, Guillaume 1998: 61, Mango 1986: 721, WEIPERT 2009.

22 This is admittedly a simplified account of the canonical theory of case endings in Arabic linguistic thought, which abstracts away from case-assigners such as the covert element referred to as $i b t i d \bar{a}^{\prime}$ by the Arab grammarians. See GUILLAUME 1998: 44-58 for details.

23 It would be tempting to restate in modern terms this theoretical scenario by assuming a pattern of complementary distribution. On this view, three parts of speech are found in Arabic, two of which (verb, 
lary, the phonological realization of the case ending assigned to the noun depends precisely on the nature of the constituent that precedes it. The particle assigns the case ending $i$ to the noun; the verb assigns the case ending $u$ to the first instance of a noun in the utterance, as well as the case ending $a$ to the second instance of it; and a covert constituent, which has a verb-like and/or a particle-like nature, assigns the case ending $u$ to the noun. For instance, in the utterance daraba Zaydun 'Amran 'Zayd hit 'Amr', the verb daraba assigns the case ending $u$ to the proper noun Zayd and the case ending $a$ to the proper noun 'Amr. ${ }^{24}$ A theory of case along these lines is formal in the sense that no semantic considerations are invoked to explain the phonological realization of the case endings, the position of the utterance constituents only being relevant. Keeping to the example daraba Zaydun 'Amran, there is a tendency for the Arab grammarians to elaborate only very minimally upon the idea that the case ending $u$ is assigned to the agent of the utterance Zayd, and the case ending $a$ to its object 'Amran. ${ }^{25}$

However, al-Astarābā $\overline{1} \overline{1}$ takes the opposite approach by affirming that the case ending $u$ is assigned to any necessary part of the utterance ( $\left.{ }^{c} u m d a\right)^{26}$, such as the subject and the predicate, and the case ending $a$ is assigned to any optional part of it (fadla), such as the object and the other complements. ${ }^{27}$ A parallel with the modern linguistic notion of minimum clause will be useful to elucidate al-Astarābādī̄'s theory of case endings ${ }^{28}$, and especially the dialectics between ' $u m d a$ and fadla ${ }^{29}$ upon which this theory is founded. To begin with, let us consider the utterance John ate an apple, from which we can derive the minimum clause John ate if we omit its object an apple. The relevant fact about this omission is that it deletes a portion of meaning, e.g., an apple, from the utterance, e.g., John ate an apple, without compromising the latter's overall semantics (and grammaticality) and yielding a minimum clause that is made of a subject and a (verbal) predicate, e.g., John ate. The same remarks apply to the utterance John ate yesterday, if we omit its complement of time

particle) assign the case ending and the other (noun) receives it. Nonetheless, the ability of the verb to receive the case ending (cp. the imperfective forms yaf'alu, yaf'ala) falsifies an interpretation of this sort.

24 See the end of this paper for further examples concerning the particle and the noun to which it assigns the $i$-ending.

25 On the contrary, modern Western linguistics is inclined to endorse this interpretation.

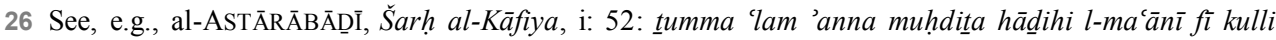
smin huwa l-mutakallimu [...] wa-kada ā l-'ámilu fì kulli wāhidin min-a l-mubtada'i wa'l-habari huwa l-

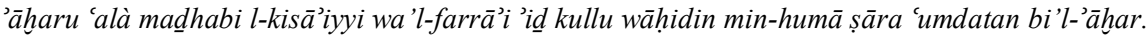

27 See, e.g., al-ASTĀRĀBĀD̄Ī, Šarh al-Kāfiya, i: 52 wa-hntulifa fì nāṣibi l-fadalāti fa-qāla l-farrā’ huwa lfi'lu ma'a l-fāil wa-hwa qarībun 'alà l-'aṣli l-madxkūri 'ị bi-'isnādi 'aḥadi-himā 'ilà l-'âhari șārat [i.e., l-ma'ānis: see the previous footnote] fadlatan.

28 This is a simplified overview of al-Astarābād̄ī's theory of case endings, which says nothing about the case ending $i$. A more complete presentation of this theory could probably treat the case ending in question as a syntactically-conditioned allomorph of the case ending $a$ : $a$ becomes $i$ when preceded by a preposition (e.g. mas $\bar{a}$ an 'in the evening' $\rightarrow f \hat{\imath}$ l-mas $\vec{a} i$ 'id.'), except for diptotes. Cp. GuILlaume 1998: 59-62 and BoHas, Guillaume, Kouloughli 1990: 66-68.

29 This parallel is for clarification purposes only. It does not imply any assimilation of the modern notion of minimal clause to al-Astarābādī's notions of 'umda and faḍla. More research would be needed on this subject. 
yesterday. This semantic situation is tantamount to saying that in the minimum clause only the subject and the (verbal) predicate qualify as the necessary parts of the utterance, not unlike the 'umda in al-Astarābādī's view, whereas the object and other complements are an optional part of it (cp. their omittability), not unlike the fadla in his view. By way of illustration, the utterance Zaydun muntaliqun 'Zayd is leaving' includes two instances of 'umda (the subject Zaydun and the predicate muntaliqun), whereas the aforementioned object 'Amran is an instance of fadla similarly to complements of time and manner (e.g., mas $\vec{a}$ 'an 'in the evening', al-battata 'surely'). This theory of case endings is semantic since it has at its core the notions of 'umda and fadla, which ultimately are but two sets of pieces of information one speaker conveys to another, such as substance, attribute (cp. the subject and the predicate that define the 'umda), time, manner (cp. the complements of time and manner that define the fadla). ${ }^{30}$

The mainstream formal theory of case endings and al-Astarābādī's semantic theory of case endings seem to be equally capable of explaining the presence of case endings in a simple utterance like daraba Zaydun 'Amran, where the case endings $u$ and $a$ can be analyzed either as two outcomes of the verb daraba that precedes the nouns bearing them; or as an opposition necessary vs. optional part of the utterance. However, al-Astarābādī̄s semantic theory of case endings is seemingly superior to its formal counterpart when it comes to a more complex instance of utterance, which involves a passive form. Arabists have in the past noticed the difficulties experienced by the mainstream formal theory of case endings with respect to al-Astarābādī's theory, but the passive utterances they have taken into consideration belong to a somewhat ad hoc set of utterances often mentioned in the Arab grammarians' treatises, e.g. sìra farsahänni 'Two leagues were travelled' ${ }^{31}$ Here, we would like to discuss the same theoretical scenario by means of a more concrete instance of passive utterance, drawn from the linguistic data gathered by Sībawayhi. The author of the Kitäb mentions a kind of passive utterance, in which the internal object displays an alternation of case endings $u / a$, e.g., duriba bi-hi darbun daīifun / darban da ī ífan 'a weak blow was hit with it' ${ }^{32}$ A certain amount of idealization is undeniable in this linguistic data (cp. the stereotyped example duriba etc.), but the very alternation of case endings $u / a$ in it plausibly points to a real context of dialectal variation. ${ }^{33}$

As has just been illustrated, the mainstream formal theory predicts that the verb assigns the case ending $u$ to the first instance of a noun in the utterance, so that it accounts for one member of the alternation only, i.e., darbun da îfun, leaving the other, i.e., darban da îfan, unaccounted for. By contrast, al-Astarābādī’s semantic theory of case endings provides a straightforward explanation for both members of the $u / a$ alternation by interpreting them as two effects of two different communicative attitudes on the part of the speaker. If the speaker places informational saliency on the piece of information 'weak blow' (cp. the

30 This theory has also a pragmatic dimension insofar as it takes into account the role of the speaker and his intentions: see LARCHER 2014: 267-316.

31 See Bohas, Guillaume, Kouloughli 1990: 65 and Owens 1988: 183.

32 Quoted in OWENS 2006: 95.

33 See OWENS 2006: 94-5, who also considers the possibility of free variation. However, a nonvariationist interpretation is also possible. This interpretation, which invokes pragmatic factors such as a different distribution of the informationally salient constituent, is discussed immediately below. 
notion of internal object in modern Western linguistics), this element functions as a necessary part of the utterance ('umda), and therefore receives the case ending $u$. If the speaker does not place informational saliency on the piece of information 'weak blow', the same element functions as an optional part of the utterance ( fadla), thereby receiving the case ending $a .^{34}$

Insofar as al-Astarābā from the formal theory of case endings that the Arab grammarians conservatively accepted and transmitted from one generation to another, we can credit him as a bearer of semantic originality in Arabic linguistic thought. His semantic originality is particularly remarkable in light of its ability to analyze certain facets of the utterance that Arabic linguistic thought traditionally takes great pains to analyze by means of its formal approach. That said, the disruption that al-Astarābād̄i represents with respect to mainstream Arabic linguistic thought should not prevent us from recognizing his continuity with it. ${ }^{35}$ Suffice it here to mention two facts. In first place, the notion of fadla is already found in the work by alMubarrad (d. 285/898). ${ }^{36}$ Secondly, and more importantly, al-Astarābādīi himself presents his semantic theory of case endings as a development of some views held by al-Farrä (d. $207 / 822)^{37}$, who is well known for his strong interest in the linguistic exegesis of the Koran (cp. his huge work Ma'ānī l-Qur'ān). ${ }^{38}$ The epistemological link between al-Farrä and alAstarābādī therefore provides the crucial indication that the semantic originality revealed by Arabic linguistic thought may possibly find its ultimate origin in the linguistic exegesis of the Koran.

34 This notion merely serves a clarification purpose. The question whether it can be assimilated to the notion of maf $\bar{u} l$ mutlaq is not relevant here. Consequently, the difference in terms of case-assignment between the Western notion of internal object, as applied here, (alternation of case-endings $u / a$ ) and that of maf'ül mutlaq (case-ending a only) raises no interpretive difficulties.

35 In Guillaume's own words: "Il s'agit là, incontestablement d'une rupture avec ce qui est alors devenu, depuis plus d'un siècle, la «doctrine officielle» de la plupart des grammairiens arabes; cependant cette rupture $[\ldots]$ se fonde sur des tendances attestées depuis longtemps dans la tradition arabe." (GUILLAUME 1998: 60)

36 AHMED TAHA 2008: 100.

37 For instance, al-Astarābād̄i derives the semantic 'autonomy' of the 'umda-constituents mubtada' and habar (as opposed to the semantic 'dependency' of the fadlla-constituents) from their capability of governing each other, a theoretical construct that he ascribes, among others, to al-Farrā'. This is apparent from the passage quoted above in connection with the notion of 'umda: wa-kad̄a l-'amilu fì kulli wāhidin min-a l-mubtada'i wa'l-habari huwa l-'āharu 'alà madhabi l-kisā'iyyi wa'l-farrā'i 'id kullu wāhidin min-humā șāra 'umdatan bi 'l-'āhar (al-ASTĀRĀBĀD̄Ī, Šarḥ al-Kāfiyah, i: 52).

38 For instance, in this work al-Farrā' discusses mubtada"s and habar's capability of governing each other, of which al-Astarābā $1 \overline{1}$ will avail himself to develop his formulation of the notion of ${ }^{c} u m d a$ (cp. the locus probans mentioned in the previous fn.). See, e.g., al-FARRĀ', Ma'ān̄ l-Qur'ān ii: 302: waqawlu-hu wa-qālati mra'atu fir'auna qurratu 'aynin lī wa-la-ka rufi'at qurratu 'aynin bi-'idmāri huwa wa-mitlu-hu fí l-qur'āni kațīun yurfa'u bi-'iḍmār. In this passage al-Farrā's analyzes the words of Pharaoh's wife reported in the Quranic verse 28:9 ("Said Pharaoh's wife, 'He will be a comfort to me and thee...", Arberry's translation) as a mubtada' (i.e., qurratu 'aynin) that receives its $u$-ending from a covert habar, i.e., huwa, which governs it. On the linguistic aspects of al-Farrā's $M a a^{\prime} \bar{a} n \bar{l} l-Q u r^{\prime} \bar{a} n$, see also BERTONATI 1988. 


\section{Ibn Hišām and the Arabic definite article}

The attentive reader will have noticed that the formal theory of case endings, just outlined in the previous section, in turn hinges on a classification of the parts of speech, namely the tripartite classification of Arabic words into noun, verb, particle (ism, fi l, harf). One of the tersest formulations of this classification goes back to the incipit of Sībawayhi's Kitāb and has enjoyed great fortune up until recent times, as virtually no modern grammar of literary Arabic discounts the model of classification of Arabic words into ism, ficl, harf: "The words are noun, verb and particle" (fa-l-kalimu smun wa-fi lun wa-harf). ${ }^{39}$ The conservatism that pervades the Arab grammarians' classification of parts of speech is self-evident.

To this we could add that the classification in question also entails a certain amount of formalism, as shown by the influential analysis of the particle carried out by Sỉbawayhi in the aforementioned incipit of his Kitāb. In this passage, in fact, he does not set out a positive semantic definition of the particle (e.g., what denotes time, place, manner etc.), preferring instead to define it negatively as what is semantically neither a noun nor a verb: "the particle that occurs to [convey] a meaning, which is neither nominal nor verbal" (harfun $\check{g} \bar{a}^{3}$ a li-ma'nàn laysa bi-smin wa-lā $\left.f i{ }^{c} l\right)^{40}$

Hence, it seems safe to maintain that the formal aspect prevails over the semantic one in the analysis of the particle developed by Arabic linguistic thought from Sībawayhi onward. Concretely, the Arabic definite article is among the particles that receives an analysis of this sort as, according to a recent study by Baalbaki, ${ }^{41}$ even definiteness ( $\operatorname{ta}$ 'ri $\bar{f}$ ), which represents its key property, is one of "the technical terms which refer to formal aspects" in the Kitāb (e.g., the position the article fulfills with respect to the noun). Such a formal (positional, etc.) analysis will also become conservative when the subsequent grammarians continue to pursue it, assigning a marginal role to the semantic properties of the Arabic definite article that they could identify, such as the latter's reference to previous knowledge ('ahdiyya). However, a case can be made for a semantic treatment of the Arabic definite article on the part of Ibn Hišām.

Ğamāl al-Dīn Abū Muhammad 'Abd Allāh b. Yūsuf b. 'Abd Allāh b. Yūsuf b. Aḥmad b. 'Abd Allāh b. Hišām al-Naḥwī was a faqīh and grammarian. He was born in 708/1310 in Cairo, where he spent most of his life and died in 761/1360. ${ }^{42}$ As a Šāfi ${ }^{c} \overline{1}$ doctor, he became professor of Quranic exegesis (tafsīr) at the Qubba Manșūriyya in Cairo. As a grammarian, he authored the treatise Mugnī l-labīb 'an kutub al-'a'ārīb, which won the complete admiration of Ibn Haldūn (d. 808/1406). This is a description of syntax arranged to start from each Arabic harf in alphabetical order. In the Mugnni l-labīb 'an kutub al-'a'ā rīb, Ibn Hišām also deals with the Arabic definite article, which he regards as an instance of particle, and provides a more fine-grained account of the aforementioned notion of 'ahdiyya by classifying

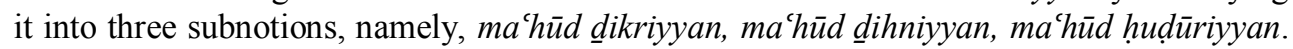

39 SīBAWAYHI, Kitāb, i: 12. Cp. also VERSTEEGH 1997: 242.

40 SīBAWAYHI, Kitāb, i: 12. Cp. also VERSTEEGH 1997: 242.

41 BAALBAKI 2008: 173. Cp. also the beginning of this paper for the interplay between the (prevailing) formal approach and the (marginal) semantic approach in Sïbawayhi's work.

42 FLEISCH 1986: 801-2, GULLY 1995: 1-26, 266.

jais • 17 (2017): 97-113 
They roughly correspond to the modern linguistic constructs of textual anaphora, extratextual anaphora, and deixis, respectively. ${ }^{43}$

Thus, by means of his tripartite and semantically-oriented classification of the Arabic definite article, Ibn Hišām brings forth a perspective that, because of its uniqueness within Arabic linguistic thought, is undeniably original; although this assertion must be tempered by the acknowledgement that in the same classification Ibn Hišām foregrounds a significant trait of continuity with mainstream Arabic linguistic thought. In fact, as just alluded to, Ibn Hišām takes as the departure point of his tripartite and semantically-oriented classification of the Arabic definite article the traditional (and marginal) notion of 'ahdiyya. A dialectics between originality and continuity therefore emerges in Ibn Hišām's linguistic thought, which constitutes a notable aspect of similarity with al-Astarābādī's thought. ${ }^{44}$ Another aspect of similarity that one grammarian shares with the other is a strong background in the linguistic exegesis of the Koran — as just alluded to, Ibn Hišām was appointed professor of this discipline. ${ }^{45}$

\section{Ibn al-Qaț̦āa and Arabic prefixation}

'Alī b. Ğacfar b. 'Alī al-Šantarīnī al-Sacdī al-Șiqillī, also known as Ibn al-Qațtầ', was an anthologist, historian, grammarian, lexicographer and poet, who was born in Sicily in 433/1041. In that period the island was first ravaged by civil war, then conquered by the Normans, leading him to leave Sicily in 1061. After a short stay in Andalusia, he finally settled in Egypt, where he died in 515/1121. There he circulated the al-Sihâa $h$ dictionary by al-Ğawharī (d. 398/1007-8), of which he is traditionally said to be the greatest transmitter and which he received from his teacher Ibn al-Birr (d. around 493/1100). ${ }^{46}$

According to the Arabic linguistic tradition, Ibn al-Qatț $\operatorname{a}^{-}$is the author of two thematic glossaries (mubawwab) devoted to the morphological patterns ('abniya) found in the kaläm $a l-{ }^{\prime} A r a b$. While one thematic glossary, the so-called Kitāb al-'af'āl, only deals with verbal patterns, the other, transmitted under the title Kitāb 'abniyat al-'asmä' wa'l-'af'a $\bar{l}$ l wa'lmașādir, revolves more broadly around the patterns of nouns, verbs and the hybrid category they give rise to: the verbal noun (mașdar). ${ }^{47}$

43 See IBN HIŠĀM, Muginni l-labīb 'an kutub al-'a'ārî̀b, i: 106, 108. This passage reads as follows: 'al 'alà talātati 'awğuhin [...] wa'l-țān̄ 'an takūna harfa ta'rīfin wa-hya naw'āni 'ahdiyyatun wa-ğinsiyyatun wa-kullun min-humā talātatu 'aqsāmin fa'l-'ahdiyyatu 'immā 'an yakūna mașhūbu-hā ma'hūdan dikriyyan [...] 'aw ma'hüdan dihniyyan [...] 'aw ma'hüdan hudüriyyan. The parallel between machüd

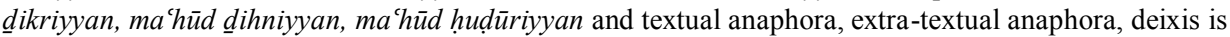
proposed by GULLY 1995: 146-8. Cp. also VERSTEEGH 1997: 265.

44 See the end of the previous section.

45 See also the end of the previous section.

46 RizZITANO 1986: 818-19, CAPEZIO 2015: 139-41. See also the editor 'Abd al-Dāyim's Introduction to IBN al-QATTT Ā', Kitāb 'abniyat al-'asm $\bar{a}^{\prime}$ wa'l-'af'âl wa'l-mașädir: 19-23 and the other contributions in this volume.

47 BAALBAKI 2014: 258-60, 264-5. 
The Kitāb 'abniyat al-'asmä' wa'l-'af'āl wa'l-mașādir is of particular interest here because of the potential it bears in terms of semantic originality. A good indication of its general tendency to originality is its inclusion of all sorts of Arabic morphological patterns, even those not mentioned by Sībawayhi, in its collection. Moreover, the Kitāb 'abniyat al'asma $\bar{a}^{\prime} w a$ 'l-'af'āl wa'l-mașädir opts to treat the verbal noun as a self-contained object of investigation, in sharp contrast to previous works of the same genre, and in so doing relies upon a definition of verbal noun that is semantic, to the extent that it decomposes this kind of lexeme into a peculiar combination of two semantic primitives, i.e, the nominal and verbal properties (componential analysis). ${ }^{48}$ From this vantage point, the choice of pinpointing the verbal noun as a self-contained object of investigation is fairly indicative of the particular tendency to semantic originality of the Kitāb 'abniyat al-'asma $\bar{a}^{\prime}$ wa'l-'af'a $\bar{a}$ wa'l-mașādir and of its author Ibn al-Qatțā' In the remainder of this section, we further corroborate the hypothesis that an original attitude to semantic originality informs the Kitāb 'abniyat al-'asm $\bar{a}^{\prime}$ wa'l-'af'āl wa'l-mașādir by means of a case study of a fundamental ingredient of Arabic morphological patterns - affixation-, and especially in the interpretation of it offered by Ibn al-Qatțā' in this treatise.

Within the theoretical framework of the Kitāb 'abniyat al-'asmāa' wa'l-'af'âl wa'l-mașādir, affixation (ziy $\bar{a} d a$ and related terms: $z \bar{a}^{3} i d$ etc.) in essence has a consonantal nature and performs the function of increasing the length of morphological patterns. The root (așl) shares with affixation the same nature and function, as it manifests itself as triconsonantal, quadriconsonantal and so on. Both consonantal affixes and root consonants can co-occur with vowels when increasing the length of morphological patterns. This theoretical framework is apparent in the conceptual structure of the Kitäb 'abniyat al-'asm $\bar{a}^{\prime}$ wa' $l$-'af'äl wa'lmașādir, which organizes the morphological patterns according to a criterion of increasing length of root consonants and consonantal affixes, owing much to Sībawayhi in this regard. By way of illustration, Sībawayhi mentions the morphological patterns fucl, fucul, 'af $u l$ precisely in this order of increasing length, as does Ibn al-Qatțầ in his Kitāb 'abniyat al'asma $\bar{a}^{\prime}$ wa'l-'af'āl wa'l-mașādir. What is more, the latter grammarian, like the former, makes use of the fundamental terminological pair așl/zāa id. ${ }^{49}$

Since the criterion of increasing length involves no semantic factor and revives the criterion of increasing length adopted by Sībawayhi, the theoretical framework of the Kitāb 'abniyat al-'asmä' wa'l-'af'âl wa'l-mașādir is plausibly one of the many instances of formal and conservative approach that characterize Arabic linguistic thought. This observation does not deny the Kitāb 'abniyat al-'asmä' wa'l-'af'āl wa'l-mașādir the semantically origi-

48 From a textual perspective, this choice is reflected in the conceptual structure of the Kitäb 'abniyat al'asma $\bar{a}^{\prime}$ wa'l-'af'âl wa'l-mașādir, which deserves a separate treatment to the verbal noun patterns, contrary to previous works, such as the Kitāb al-Istidrāk authored by al-Zubaydī (d. 379/989). See BAALBAKI 2014: 285.

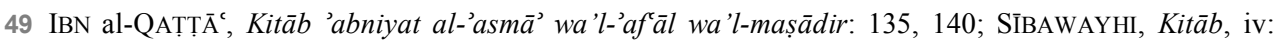
242-245. For simplicity's sake, the terminological pair $a s ̦ l / z \bar{a}^{3} i d$ is rendered here as root/affix in the wake of BAALBAKI 2002: 1. This terminological pair is effectively part and parcel of a broader lexical set, which also includes ziyāda (affixation) mazìd (affixed) etc. See, e.g., IBN al-QAȚṬĀ', Kitāb 'abniyat al-'asmä' wa'l-'af'äl wa' 'l-mașādir: 92, 109. But cp. also LARCHER 1995, who brings solid arguments in favor a more accurate translation — and conceptualization —of the terminological pair așl/za $\bar{a}^{3} i d$. 
nal character we have alluded to immediately above and is instead meant to highlight the aspects of continuity that this treatise instantiates along with its aspects of originality.

Returning to the comparison between the Kitāb 'abniyat al-'asma $\bar{a}^{\prime}$ wa'l-'af'a $\bar{l}$ wa'lmașādir and the Kitāb, a closer look at the passages that expound the morphological pattern $f u^{\prime} u l$ reveals a certain difference between the two treatises. While Sỉbawayhi exemplifies the morphological pattern $f u^{c} u l$ by means of the word ğumud without explaining the latter's meaning, Ibn al-Qatțāc supplements Sībawayhi's example with the gloss 'name of a mountain' (ism ğabal). ${ }^{50}$

Insofar as this gloss helps to elucidate the meaning of the word ğumud and is not found in Sībawayhi's work, it can qualify as a sort of semantic originality on the part of Ibn alQatțā'. However, the semantic originality under scrutiny is not as crucial, given that it is not original to Ibn al-Qatțāt : the practice of glossing obscure words, the meaning of which Sîbawayhi omitted to record, is typical of the genre of thematic glossary to which the Kitāb 'abniyat al-'asmä' wa'l-'af'āl wa'l-mașādir belongs. ${ }^{51}$ It is also worth noting that the semantically-oriented practice of glossing obscure words mainly arose and developed in the milieu of the linguistic exegesis of the Koran, as evidenced by the type of thematic glossary traditionally known as garīb al-Qur'ān. ${ }^{52}$ It follows that the original glosses that Ibn alQatțā' associates with the morphological patterns in the Kitāb 'abniyat al-'asma $\bar{a}^{\prime}$ wa' $l$-'af'a $\bar{l}$ wa'l-mașädir lack conceptual originality yet bear testimony, again (cp. the two previous sections), to an epistemological link between semantic originality in Arabic linguistic thought and the background of linguistic exegesis of the Koran.

On the other hand, a major trait of semantic originality that we can in all likelihood fully ascribe to Ibn al-Qatțāc alone emerges from a careful examination of a passage of the Kitāb 'abniyat al-'asmā' wa'l-'af'āl wa'l-mașādir, drawn from its chapter on affixes (Bāb hurūf al-zawāid) ${ }^{53}$ The passage in question describes the $w$-affix as follows: " $w$ can be inserted within a noun or a verb, but not in first position, except for the [expression of] oath; it can be inserted within them in second position, as in kawtar" (wa'l-wāwu tulhaqu fí

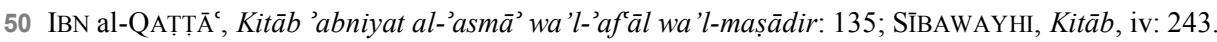

51 BAALBAKI 2014: 60. In principle, we can hypothesize that Sỉbawayhi omitted to record the meaning of ğumud since it was a toponym well-known to him and to the educated people of his time; and that, on the contrary, Ibn al-Qatțāc felt the need to expound the meaning of the same word as, centuries later after Sỉbawayhi, it had become incomprehensible to Ibn al-Qaț̣āa himself and to his educated audience. However, textual research militates against this hypothesis. The early lexicographer Abū 'Ubayda (d. 209/824), who died about thirty years after Sibawayhi, glosses precisely the word ğumud as the name of a mountain located in Najd under the sphere of influence of the Banū Nașr tribe, which plausibly shows that this word was already obscure in Sïbawayhi's time. Abū 'Ubayda's gloss, which had been transmitted by the geographer Yāqūt (d. 626/1229), reads as follows: al-ğumudu bi-ḍammatayni qāla abū 'ubaydata huwa ğabalun li-bañ̄ nașrin bi-nağd (cp. YĀQŪT, Mu '̆gam al-Buldān, ii: 161). See also BAALBAKI 2014: 19, 165 for further information about Abū 'Ubayda. However, it is also worth pointing out that the different kinds of linguistic analysis carried out by Sïbawayhi and Abū 'Ubayda (naḥw and $l u \dot{g} a$, respectively), might have plausibly influenced the absence vs. the presence of glosses associated with nominal patterns and related words such as $f u^{\prime} u l$ and $\check{g} u m u d$.

52 BAALBAKI 2014: 63.

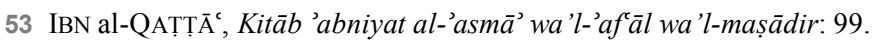


l-ismi wa'l-fíli illā anna-hā lā tulhaqu awwalan illā fì l-qasami l-battata wa-tulhaqu țāniyatan fi kawtar)..$^{54}$

The passage of the Kitāb that describes the same affix differs markedly from the previous passage in that it does not admit the occurrence of $w$ in first position, i.e., as an affix that can occur at the beginning of a noun or verb: "regarding $w$, it can be inserted in second position, as in hawqal" (ammā l-wāwu fa-tuzādu täniyatan fï hawqal). ${ }^{55}$

In essence this difference boils down to the interpretation of the expression of oath, which in the variety of Arabic investigated by Sïbawayhi and Ibn al-Qațtā' frequently takes on the form of a string wa, as in wa-llāhi lā af'alu. ${ }^{56}$ On the one hand, Sībawayhi purports that $w a$ is a sort of variant of the particle $b i$, underscoring two syntactic properties of this expression of oath. First, wa has the ability to co-occur with the name Allāh, just like the particle $b i$ does. Second, $w a$ has the ability to assign genitive, just as the particle $b i$ does. In Sībawayhi's own words: "the $b \bar{a}^{\text {}}$ [that assigns] genitive serves to join and connect [words]

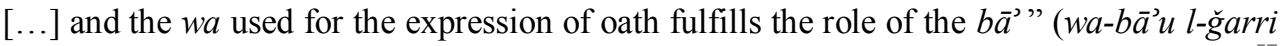
inna-mā hiya li-l-ilzāq wa'l-ihtilāți wa'l-wāwu llatī takūnu li-l-qasami bi-manzilati l-bā'). ${ }^{57}$ In sum, due to its focus on two syntactic properties of $w a$, which involve no semantic factors (co-occurrence, genitive-assignment), Sībawayhi's analysis of $w a$ is formal.

On the other hand, it can be argued that Ibn al-Qatța ${ }^{-c}$ 's affixal analysis of wa, which we have just illustrated, is semantically-oriented. The argument is built as follows. First, as discussed at the end of the Introduction, from Sībawayhi onward the affix that performs the function of $i l h \bar{a} q$ is combined with a pure morphological pattern, as is the case for faw'al (cp. kawtar), or fa $w a l$ (cp. ğadwal). Second, the affixal wa that co-occurs with the name Allāh (e.g., wa-llāhi lā af́alu) is not combined with a pure morphological pattern, but with a morphological pattern plus the article al (cp. the string $\mathrm{Al}$ in Alläh). On these grounds, this instance of $w a$ must perform a function other than ilha $\bar{a}$. Third, as discussed at the end of the Introduction, from Sībawayhi onward the only other function, besides ilhāq, assigned to the affix by even the formal approach of Arabic linguistic thought is semantic. Hence, by exclusion, the affixal wa that co-occurs with the name Allah performs a semantic function: in this case, that of conveying the meaning of oath.

A semantically-oriented analysis along these lines, which is culled from Ibn al-Qatța ${ }^{-c} s$ twofold characterization of the $w$-affix as word-initial and related to oath (i.e., wa), appears to stand as an interesting trait of originality within Arabic linguistic thought. It is very instructive in this regard that three centuries after Ibn al-Qatța-'s death and beyond, both the erudite works al-'Itqān fí̀ 'ulüm al-Qur'ān, authored by al-Suyūṭī (d. 911/1505), and Tāğ al'Arūs, authored by al-Zabīdī (d. 1205/1790), provide thorough and exhaustive reviews of the several interpretations associated with the string $w a$ in all of its contexts of occurrence, yet neither of them mentions Ibn al-Qatțā's analysis of wa in terms of an affix when they

\footnotetext{
54 IBN al-QATṬ̂̄', Kitāb 'abniyat al-'asmäa wa l-'af'āl wa 'l-mașādir: 101.

55 SīBaWAYHI, Kitāb, iv: 237.

56 SīBAWAYHI, Kitāb, iv: 217. Cp. also Wright 1896, i: 279.

57 SīBaWaYhi, Kitāb, iv: 217.
}

jais • 17 (2017): 97-113 
discuss the instance of $w a$ that expresses oath. ${ }^{58}$ The only analysis referred to in this connection by al-Suyūṭ̂ and al-Zabīdī is that of Sībawayhi, as is easily gleaned from a simple comparison between his definition of the wa that expresses oath, which we have quoted immediately above, and their definitions of the same instance of wa. Thus, al-Suyūṭi asserts that "the $w a$ that expresses oath is a genitive-assigner" (fa'l-ğârratu wāwu l-qasam). ${ }^{59}$ Likewise, al-Zabīdī states that "the wa that expresses oath is an alternant of bi" (wāwu $l$ qasami ... badalun min al-bä $)^{60}$

What is more, at the beginning of the chapter forty-one of his grammatical treatise alMuzhir fì 'ulūm al-luga wa-anwā'i-hā al-Suyūṭ̂̄ explicitly mentions the treatise Kitāb 'abniyat al-'asmā' wa'l-'af'āl wa'l-mașādir, in which Ibn al-Qațāa analyzes the $w$-affix as word-initial and related to oath (i.e., $w a)^{61}$ and yet in the same work al-Suyūtī refrains from mentioning this analysis by Ibn al-Qatta ${ }^{-c}{ }^{62}$ It is of the utmost importance to note at this point that the failure to mention Ibn al-Qatțā's affixal and semantically-oriented analysis of the wa that expresses oath on the part of al-Suyūțī and al-Zabīdī cannot necessarily be ascribed to their ignorance of the morphological work of the Sicilian grammarian. On the one hand, as we have just observed, in the Muzhir fí 'ulūm al-lugia wa-anwā'i-hā al-Suyūṭ̂ explicitly and copiously cites Ibn al-Qațtā's Kitāb 'abniyat al-'asmä’ wa'l-'af'āl wa'l-

58 The lack of an analysis of $w a$ in terms of a word-initial affix in al-Suyūṭ̂̀'s and al-Zabīdī's work is regarded here as a sort of qualitative evidence of the original nature of such an analysis on the part of Ibn al-Qatțā (in the sense that this kind of evidence focuses on how al-Suyūtī and al-Zabīdī used to deal with the body of knowledge elaborated on by their predecessors, Ibn al-Qatțā included). It would be also possible to provide quantitative evidence to the same effect. The gist of the proposal is to study the grammatical literature between Sïbawayhi's Kitāb and Ibn al-Qațtạ 's treatise to ascertain whether the Sicilian grammarian really developed an original analysis or took it from one of his predecessors. The scope of this paper prevents a thorough presentation of this kind of quantitative evidence. However, quantitative evidence of this sort is at least in part implied by the qualitative evidence adduced in this study. In fact, the tendency to encyclopedism and erudition on the part of al-Suyūṭ̂̄ and al-Zabīdī implies that, in order to eruditely enumerate all of the possible analyses of $w a$ (qualitative evidence), they had to check and peruse the grammatical literature between Sïbawayhi's Kitāb and Ibn al-Qațțā's treatise (quantitative evidence), included those works that are lost to us. For instance (see BAALBAKI 2014: 86-7), in the treatise al-Muzhir fì 'ulūm al-luğa wa-anwā'i-hā (i: 453, ii: 275-6, 289) al-Suyūți takes extracts from the Kitāb al-Nawādir authored by Yūnus Ibn Habīb (d. 182/798), one of Sỉbawayhi's teachers, who is also mentioned by Ibn al-Qaț̣ā' among the sources of his treatise (see IBN al-QAȚȚĀ', Kitāb 'abniyat al-'asmā' wa'l-'af āl wa'l-mașādir: 90)

59 al-SUYŪṬ̄, al-'Itqān fì 'ulūm al-Qur'ān, ii: 303.

60 al-ZABĪDĪ, Tāğ al-'arūs, xl: 520 (s.v. al-wāw al-mufrada).

61 The locus probans is the following: dikru 'abniyati l-'asmā’i wa-hașri-hā qāla abū l-qāsimi 'aliyyun-i bnu ğa'fara l-sa'diyyu l-luġawiyyu l-ma'rūfu bi-bni l- qațtāci fì kitābi l-’abniyah (al-SUYŪṬ̄̄, al-Muzhir $f_{i}$ 'ulūm al-lugia wa-anwā' $i-h \bar{a}$, ii: 4). In this passage, the Kitāb al-'abniya the Egyptian polymath refers to is precisely the Kitāb 'abniyat al-'asmā' wa'l-af'āl wa'l-mașādir, as is inferred from the very phrase 'abniyat al-'asma $\overline{\text { ' }}$ in the section heading dikr 'abniyat al-'asmä'.

62 See al-SUYŪṬ̄, al-Muzhir fì 'ulūm al-lug்a wa-anwā'i-hā, ii: 10-12. In this passage, the Egyptian polymath includes ', $t, y, m$ and even $h$, but not $w$, among the word-initial affixes (i.e., prefixes): $a l-m a z \bar{l} d u$ min-a l-tulātiyyi gayru l-muda “'afi min-hu mā tulhiqu-hu ziyādatun wāhidatun qabla l-fä̀ ' 'alà wazni 'a-f'al [...] wa-'calà tu-f'ul wa-hwa qalìlun [...] wa-'alà ya-f'al [...] wa-'calà na-f'il [...] wa-'alà ma-f'al [...] fa-ammā ziyādati l-hä’i qabla l-fä'i fa-nafā-hu ba'du-hum [...] fa-atbata-hu ba'du-hum fa-qāla yağl’u 'alà hifa'l hizabr [...] wa-qabla l-'ayni 'alà fā'il. 
mașädir, in which such an affixal and semantically oriented analysis is found ${ }^{63}$ On the other hand, al-Zabīdì's dictionary contains several loci probantes, which quote this work of Ibn al-Qatțā' To begin with, al-Zabīdī's refers to Ibn al-Qatța $\bar{a}^{c}$ as the source of some obsolete words recorded in the Tăğ al- ${ }^{\mathrm{C}} a \bar{u} \overline{\mathrm{u}},{ }^{64}$ such as qartama and qaršama, and the editors of this dictionary cite passages of the Kitāb al-'af $\bar{a} l$ by Ibn al-Qatța ${ }^{-{ }^{c}},{ }^{65}$ in which the latter effectively mentions the same words. More to the point, in the Tăğ al-'arūs al-Zabīì considers an extract from the Kitāb 'abniyat al-'asm $\bar{a}^{\prime}$ wa'l-'af'äl wa'l-mașādir itself and locates it with accuracy "at the end ( $f \bar{\imath} \bar{a} h i r)$ " of the treatise in question. ${ }^{66}$ This kind of intertextuality plausibly shows that al-Zabīdī was familiar with Ibn al-Qațtā̄'s treatises, Kitāb 'abniyat al-'asmä' wa'l-'af'äl wa'l-mașādir included. ${ }^{67}$

To summarize the main results of this section, a first examination of the Kitāb 'abniyat

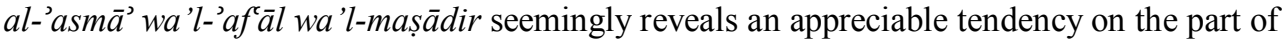
Ibn al-Qatța ${ }^{-}$toward semantically-oriented originality, which is plausibly rooted in the milieu of the linguistic exegesis of the Koran (cp. his practice of glossing obscure words, e.g., ğumud). The most conspicuous instance of an originality of this kind is his treatment of $w$ as a word-initial affix $w a$, provided as such with the meaning of oath. This semantic originality is to a certain extent due to Ibn al-Qatțā', as both his predecessors (Sībawayhi) and successors (al-Suyūtị̂, al-Zabīìi) reject an interpretation of $w$ as a word-initial affix

63 See the passage quoted in the previous footnote.

64 See, e.g., al-ZABĪDĪ, Tāğ al-'arūs, xxxiii: 259, 262 and the editors' notes therein. These passages read as follows: 'an ibni l-qațāai ka-qaršama and wa'l-qarțamatu l-qarmațatu wa-ayḍan-i l-'adwu naqalahu bnu l-qattā̄

65 See the beginning of this section.

66 See, e.g., al-ZABĪDĪ, Tāğ al-'arūs, i: 285. In this passage, al-Zabīīi records thirteen mașdars for the verb šani'a but also adds that according to al-Ğawharī its mașdars are fourteen instead: fa-șāra $l$ mağmū'u talātata 'ašara maṣdaran wa-zāda l-ğawhariyyu šinā'in ka-siḥābin fa-șāra arba'ata 'ašara bi-d̄alika. Then al-Zabīdī goes on to say that Ibn al-Qațtā too states that the mașdars of the verb šani'a are fourteen at the end of his morphological treatise: qāla l-šayh wa-staqșà d̄ālika abū l-qāsimi bni lqațtāc $i$ fì tașrīfi-hi fa-inna-hu qāla fi āhiri-hi wa-aktaru mā waqi a min-a l-mașādiri li-l-fíli l-wāhịidi arba'ata 'ašara mașdaran nahwwa šani'tu šan'an wa-awșala mașādira-hu ilà arba'ata 'ašara. In his Introduction to Kitāb 'abniyat al-'asmā' wa'l-'af'āl wa'l-mașādir: 26, the editor 'Abd al-Dāyim identifies the end of the morphological treatise referred to by al-Zabīīi as Kitāb 'abniyat al-'asmä' wa'l-'af'a $\bar{l}$ wa'l-mașādir: 382. Effectively, this passage is located at the end of the treatise in question, and is almost identical to the aforementioned passage from Tāğ al-'arūs: wa-aktaru mā waqi a min-a l-mașādiri li-l-fi'li l-wāḥidi arba'ata 'ašara mașdaran wa-țnā 'ašara mașdaran naḥwa šani'tu šan'an wa-šun'an wa-šin'an wa-šana’an wa-šanăan wa-šanăatan wa-mašna’an wa-mašni’atan wa-mašna'atan wašan'atan wa-šan'anan wa-šanānan wa-šun'anan wa-šin'anan. Cp. also Kitāb 'abniyat al-'asmä' wa'l'af'āl wa'l-mașādir: 372, where Ibn al-Qațâ̄' exemplifies the infinitive pattern fu'lān by means of yet another mașdar of the verb šani’a, notably šun'ān: wa-'alà fu' lān nahwa šani'a šun'ān.

67 To this we might add that in his treatise Mugini l-labīb 'an kutub al-'a ārō̄b, which includes an exhaustive survey of Arabic particles, Ibn Hišām too espouses the mainstream view that wāwu l-qasam is a genitive-assigning particle, as can be inferred from the phrases that he uses to describe this kind of wāw, namely harf al-wāw and wāwān yanğarr mā ba'da-humā. See IBN HIŠĀM, Muġnī l-labīb 'an kutub al-'a'ārīb, i: 225, 272, 278, which reads as follows: harfu l-wāw 'al-wāwu l-mufradatu ntahà mağmū'u mā yuḍkaru min 'aqsāmi-hā 'ilà 'ahada 'ašara [...] tanbīh za'ama qawmun 'anna l-wāwa qad tahruğu 'an 'ifādati muṭlaqu l-ğam'i wa-d̄alika 'alà 'awğuhin aḥadu-hā 'an tusta'malu bi-ma'nà 'aw [...] al-sādisu wa'l-sābi'u wāwāni yanğarru mā ba'da-humā 'iḥdā-humā wāwu l-qasam. 
and/or subscribe to a formal interpretation of $w a$, which denies the latter a semantic content in its function as a word-initial affix, instead regarding it as a genitive-assigning particle.

\section{Conclusions}

This paper has plausibly substantiated the hypothesis that Ibn al-Qatțā can be considered, along with the perhaps most famous grammarians al-Astarābādī and Ibn Hišām, as one of the few bearers of semantic originality in the context of medieval Arabic linguistic thought, as is shown by the construct of a word-initial and meaningful affix $w(a)$. Such a construct is seemingly absent in Sībawayhi's Kitāab, whereas Ibn al-Qațtā̄ posits it and identifies it with the so-called wāw al-qasam. This paper also stresses the point that the traits of semantic originality introduced into Arab linguistic thought by al-Astarābād̄ī, Ibn Hišām and Ibn al-Qatțāa share a common epistemological aspect: they possibly find their ultimate origin in the milieu of the linguistic exegesis of the Koran. Further research is needed to acquire a better understanding of how, on the whole, the original aspects of the semantic approach pursued by al-Astarābādīi, Ibn Hišām and Ibn al-Qațtāa position themselves within the historical development of Arabic linguistic thought, which witnessed at least three stagesearly, or formative, classical, and late, or post-classical. ${ }^{68}$. At the current research stage it seems safer to maintain that the semantically-oriented approach co-existed with the formal approach since the beginnings of Arabic linguistic thought, albeit in an implicit or embryonic form, so the original character of Late grammarians such as al-Astarābād̄ī, Ibn Hišām and Ibn al-Qațta $a^{-}$lies mainly in their efforts to make the semantically-oriented approach more explicit and central.

\section{Bibliography}

al-AstĀRĀBĀD̄ī, 1993. Šarh al-Kāfiya. Ḥ. B. M. I. al-Ḥifẓ̄ī (ed.), al-Riyāḍ: Hiğr li-1-Ṭibāáa wa'l-Našr wa'l-Tawzī' wa'l-I'lān.

Ahmed Taha, Z. 2008. "Maf'ūl". In K. Versteegh et al. (eds.), Encyclopaedia of Arabic Language and Linguistics, Leiden/Boston: Brill, vol. 3: 100-106.

ArAzI, A., et al. (eds.). 1999. Compilation and Creation in Adab and Lugha: Studies in Memory of Naphtali Kinberg (1948-1997). Winona Lake, IN: Eisenbrauns.

BaAlbaki, R. 2002. "Ilhạa as a Morphological Tool in Arabic Grammar". Journal of Arabic and Islamic Studies, 4: 1-26.

- 2008. The Legacy of the Kitāb. Sïbawayhi's Analytical Methods within the Context of the Arabic Grammatical Theory. Leiden/Boston: Brill.

- . 2014. The Arabic Lexicographical Tradition. Leiden/Boston: Brill.

Bertonati, S. 1988. Saggio di analisi linguistica del Ma ān̄̄ l-Qur'ān di al-Farrā̄a grammatico kufano del IX secolo. MA Thesis, Università Ca' Foscari di Venezia.

Bohas, G. / Guillaume, J.-P. / Kouloughli, D. E. 1990. The Arabic Linguistic Tradition. London/New York: Routledge.

68 See, e.g., CARTER 2007: 182-90 and SEIDENSTICKER 2008: 30. 


\section{Francesco Grande}

CAPEZIO, O. 2015. "Il trattato di metrica Kitāb al-bāri' fì 'ilm al-'arūẹ di Ibn al-Qațțâ". Quaderni di Studi Arabi, 10: 139-156.

CARTER, M. G. 2007. “Grammatical Tradition: History”. In K. Versteegh et al. (eds.), Encyclopaedia of Arabic Language and Linguistics, Leiden/Boston: Brill, vol. 2: 182-190.

DAYF, Sh. 1968. Al-Madāris al-Nahwwiyya. Al-Qāhira: Dār al-Macārif.

Page|112 al-FĀRRĀ', 1980. Ma'ānī l-Qur'ān / ed. A. Y. Nağātī, M. 'A al-Nağğār. Bayrūt: 'Ālam al-Kutub.

Fleisch, H. 1961. Traité de philologie arabe. Beyrouth: Imprimerie Catholique.

— . 1986. "Ibn Hishām". In H. A. R. Gibb et al. (eds.), The Encyclopaedia of Islam, New Edition, Leiden/Boston: Brill, vol. 3: 801-2.

GHERSETTI, A. 2017. "Systematizing the Description of Arabic: the case of Ibn al-Sarrāj”. Asiatische Studien, 71.3: 879-906.

Guillaume, J.-P. 1998. "Les discussions des grammairiens arabes à propos du sens des marques d'i'rāb". Histoire Épistémologie Langage, 20: 43-62.

— . 2007. "Grammatical Tradition: Approach". In K. Versteegh et al. (eds.), Encyclopaedia of Arabic Language and Linguistics, Leiden/Boston: Brill, vol. 2: 175-182.

Gully, A. 1995. Grammar and Semantics in Medieval Arabic. Richmond: Curzon Press.

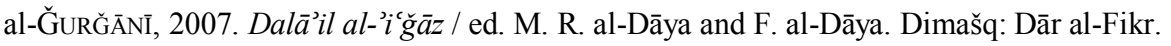

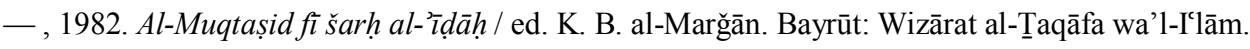

IBN HišĀM, 2005. Muġnī l-labīb 'an kutub al-'áārī̄b / ed. Ḥ. Ḥamad. Bayrūt: Dār al-Kutub al'Ilmiyya.

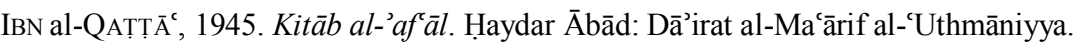

—, 1999. Kitāb 'abniyat al-'asmāa wa'l-'af'āl wa'l-mașādir / ed. A. M. 'Abd al-Dāyim. al-Qāhira: Maṭba'at Dār al-Kutub al-Mișriyya.

IBN al-SARRĀĞ, 1996. al-'Ușūl fĩ l-naḥw / ed. 'A. al-Fatlī. Bayrūt: Mu’assasat al-Risāla.

LARCHER, P. 1995. “Où il est montré qu'en arabe classique la racine n'a pas de sens et qu'il n'y a pas de sens à dériver d'elle". Arabica, 41: 291-314.

— . 2014. Linguistique arabe et pragmatique. Beyrouth: Presses de l'IFPO.

LePSCHY, G. 1966. La Linguistica Strutturale. Torino: Einaudi.

LEVIN, A. 1999. "Sībawayhi's Attitude to the Language of the Quran". In ARAZI et al. (eds.) 1999: 267-272.

MANGO, A. J. 1986. "al-Astarābādh̄̄”. In H. A. R. Gibb et al. (eds.), The Encyclopaedia of Islam, New Edition, Leiden/Boston: Brill, vol. 1: 721.

Owens, J. 1988. The Foundations of Arabic Grammar: An Introduction to Medieval Arabic Grammatical Theory. Amsterdam/Philadelphia: Benjamins.

Rizzit AnO, U. 1986. "Ibn al-Qatțā"`". In H. A. R. Gibb et al. (eds.), The Encyclopaedia of Islam, New Edition, Leiden/Boston: Brill, vol. 3: 818-19.

- . 2006. A Linguistic History of Arabic. Oxford: Oxford University Press.

Seidensticker, T. 2008. "Lexicography: Classical Arabic". In K. Versteegh et al. (eds.), Encyclopaedia of Arabic Language and Linguistics, Leiden/Boston: Brill, vol. 3: 30-37.

SīBAwAYHI, 1966-1977. Al-Kitāb / ed. 'A. M. Hārūn. al-Qāhira: Maktabat al-Hānğ̄ī.

al-SUYŪṬī, 1974. al-'Itqān fì 'ulūm al-Qur’ān / ed. M. A. Ibrāhīm. al-Qāhira: Al-Hay’a al-Mișriyya al'Āmma li-l-Kitāb.

—, [n.d.]. al-Muzhir fí̀ ulūm al-lugia wa-anwā̄i-hāa / ed. J. Al-Mawlā et al. al-Qāhira: Maktabat Dār al-Turāt.

jaif 17 (2017): 97-113 
van Bekkum, W. C., et al. (eds.). 1997. The Emergence of Semantics in Four Linguistic Traditions: Hebrew, Sanskrit, Greek, Arabic. Amsterdam/Philadelphia: Benjamins.

Versteegh, K. 1997. "The Arabic Tradition”. In VAn BeKKum et al. (eds.) 1997: 225-284.

al-ZABĪDĪ, 1965-2001. Tāğ al-'arūs min ğawāhir al-qāmūs /ed. 'A. S. A. Farrāğ. al-Kuwayt: Wizārat al-I'lām.

WeIPERT, R. 2009. “al-Astarābādhî”. In K. Fleet et al. (eds.), The Encyclopaedia of Islam THREE, Leiden/Boston: Brill, vol. 1, <http://dx.doi.org/10.1163/1573-3912_ei3_COM_22847> (06 Oct. 2017).

Wright, W. 1896. A Grammar of the Arabic Language. Cambridge: Cambridge University Press.

YĀQūT, 1957. Mu'ğam al-Buldān. Bayrūt: Dār Șādir. 